\title{
DUPLICATION AND MULTISEPTATE URINARY BLADDER: A RARE CASE REPORT
}

\section{Muhammad Fawzi Zulfikar ${ }^{1}$, Wahjoe Djatisoesanto ${ }^{2}$, Tarmono Tarmono ${ }^{3}$}

${ }^{1}$ Resident of Urology, Faculty Medicine, Universitas Airlangga, Surabaya, Indonesia/Dr. Soetomo General

Academic Hospital, Surabaya, Indonesia

${ }^{2,3}$ Staff at the Resident of Urology, Faculty Medicine, Universitas Airlangga, Surabaya, Indonesia/Dr. Soetomo General Academic Hospital, Surabaya, Indonesia

\section{ABSTRACT}

The multiseptate bladder is a congenital bladder anomaly that is very rare and often accompanied by other congenital abnormalities. This condition could result in intravesical obstruction and kidney failure in more serious conditions. A 3-yearold girl without any complaint was consulted by the Pediatric Surgery Department with postoperative cloacal type malformation anorectal (MAR) postero-sagittal anorecto-vagino-urethroplasty (PSARVUP) + sigmoidectomy. Magnetic Resonance Imaging (MRI) of the pelvis showed the appearance of four interconnected multiple fluid lesions. Cystoscopy was performed and found many septa with varied positions and forms. From the cystography during the operation, it was seen duplication of the right and left bladder. There was no further operative treatment in the field of urology because no urinary tract obstruction and normal renal function were found in this study.

Keywords: Multiseptate; multi-septum; duplication; bladder anomaly; disease

\section{ABSTRAK}

Kandung kemih multiseptate adalah anomali kandung kemih kongenital yang sangat jarang dan sering disertai dengan kelainan bawaan lainnya. Kondisi ini dapat menyebabkan obstruksi infravesical dan gagal ginjal dengan kondisi yang lebih serius. Seorang gadis berusia 3 tahun dengan tanpa keluhan dikonsultasikan oleh Departemen Bedah Anak dengan anorektal jenis cloacal pasca operasi anorektal (MAR) postero-sagittal anorecto-vagino-urethroplasty (PSARVUP) + sigmoidostomy. Magnetic Resonance Imaging (MRI) pada panggul menunjukkan munculnya empat lesi cairan ganda yang saling berhubungan. Cystoscopy dilakukan dan ditemukan banyak septa dengan posisi dan bentuk yang variatif. Dari sistografi yang dilakukan selama operasi, ditemukan duplikasi kandung kemih kanan dan kiri. Dari hal ini, tidak ada pengobatan operasi lebih lanjut di bidang Urologi, karena tidak ada obstruksi saluran kemih dan fungsi ginjal normal yang ditemukan dalam penelitian ini.

Kata kunci: Multiseptate; multi-septum; duplikasi; anomali kandung kemih; disease

Correspondence: Muhammad Fawzi Zulfikar, Resident of Urology, Faculty Medicine, Universitas Airlangga, Surabaya, Indonesia/Dr. Soetomo General Academic Hospital, Surabaya, East Java 60286. Email: mfawzizulfikar@gmail.com

pISSN:2355-8393 • eISSN: 2599-056x • doi: 10.20473/fmi.v57i3.25269

- Fol Med Indones. 2021;57:267-271• Submitted 05 Feb 2021 • Received 03 May $2021 \bullet$ Accepted 09 Aug 2021

- Open access under CC-BY-NC-SA license • Available at https://e-journal.unair.ac.id/FMI/ 


\section{INTRODUCTION}

Congenital bladder anomaly is a congenital defect in the bladder that has a relatively low incidence rate. This condition can lead to infravesical obstruction, leading to kidney failure in a more serious condition (Frimberger \& Kropp 2016). Besides, congenital bladder anomalies are the most common causes of renal failure in children (Jain \& Chen 2018, Isert et al 2020).

Multiseptate bladder is a rare congenital bladder anomaly (Karaca et al 2011). It is usually found incidentally along with other organ abnormalities. Some cases showed no clinical symptoms and these appeared physically normal. The components of the septa consisted of the mucosal layer and muscles (Wani et al 2015).

Conservative management with routine follow-up is mostly done in this case, because congenital multiseptate bladder rarely cause complications (Patel et al 2008). Surgery can be performed only if there are complications of urinary tract obstruction (Wani et al 2015, Gajbhiye et al 2015, Frimberger \& Kropp 2016, Zhan et al 2021). We reported a case of anorectal malformation with duplication and multiseptate bladder which found incidentally.

\section{CASE PRESENTATION}

A 3-year-old girl consulted from Pediatric Surgery, and diagnosed with postoperative cloacal type malformation anorectal (MAR) Posterior sagittal anorecto-vaginourethroplasty (PSARVUP) + sigmoidostomy + bladder duplication. The patient came to continue treatment in Pediatric Surgery because of a history of anorectal malformations (MAR). Patient with a history of aterm birth by Caesarian section with anus and vaginal opening was not perfect.

On physical examination of the abdominal region, there was a colonic stoma in the right abdomen, viable and good stool production. On examination of the external genital region, the external urethra (MUE) slight difficult to identify in Figure 1 and Figure 2. The production of urine is normal yellow clear. Chromosome examination results was $46, \mathrm{XX}$.

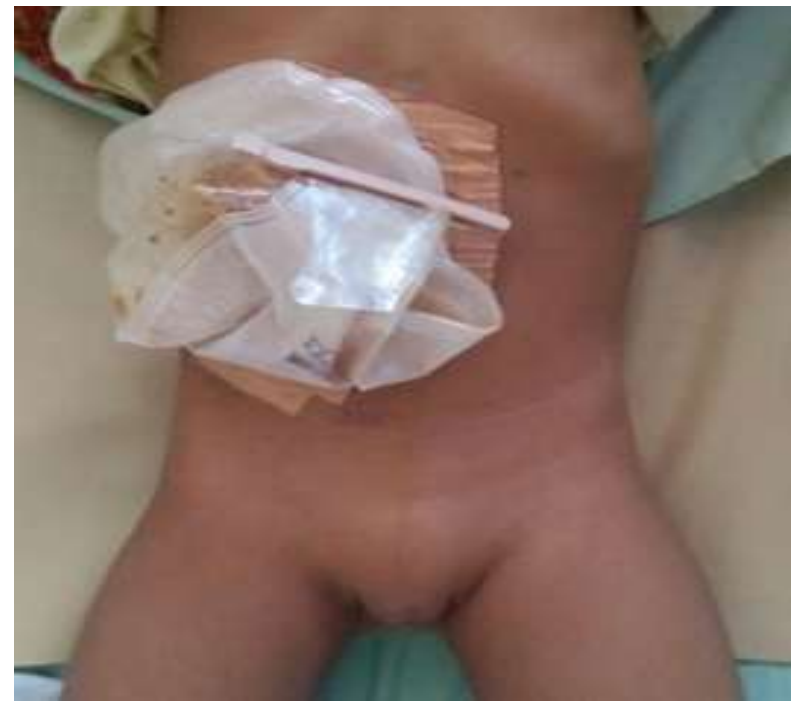

Figure 1. An overview of the abdominal region with a viable stoma

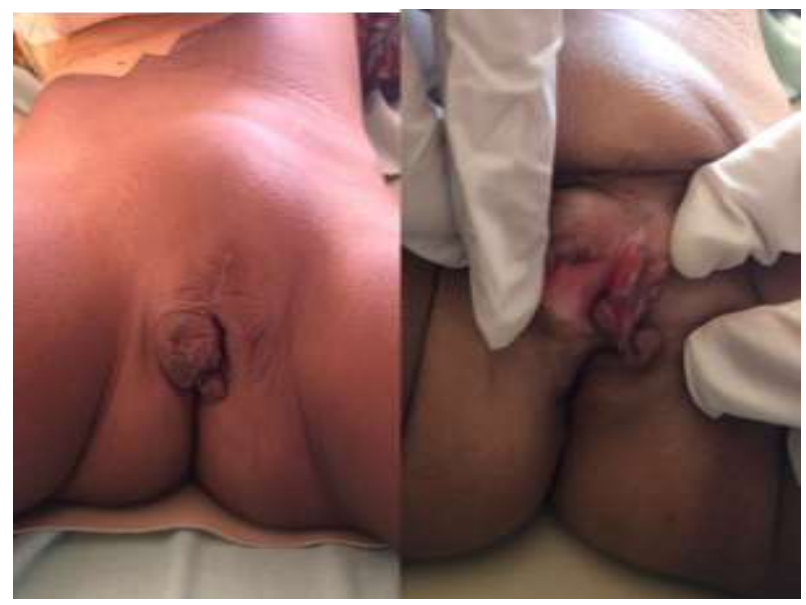

Figure 2. Overview of the external genital area

Laboratory tests were within normal limits. On the examination of the Kidney Ureter Bladder (KUB) and Computerized Tomography - Intravenous Urogram (CT-IVU), no abnormalities were found on urinary tract, but the result of genitography imaging can be seen in Figure 3. When the contrast was inserted through the meatus urethra external (MUE), it was found that the formation of the normal urethral tract and showed bladder duplication with size of $4.1 \times 2.7 \mathrm{~cm}$ and $3.9 \mathrm{x}$ $2.3 \mathrm{~cm}$. On distal loopogram examination was patent, there was no contrast leakage. Contrast appeared to fill a part of the colon, there was no fistula tract that connected the rectum with the bladder and urethra. 


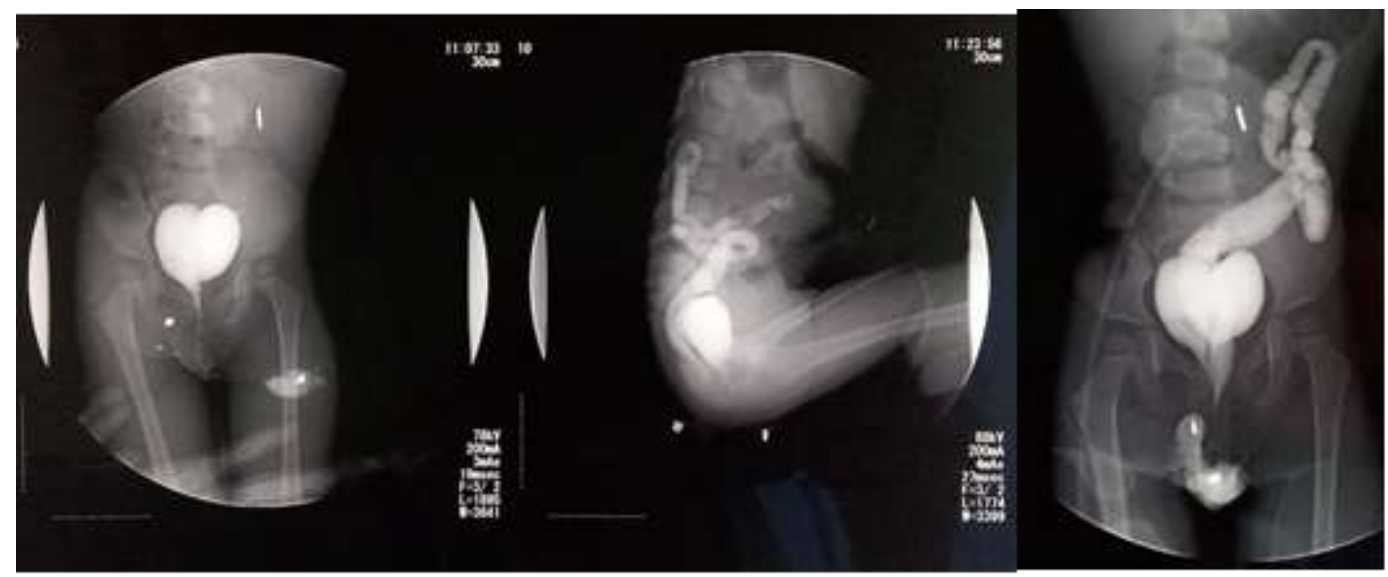

Figure 3. Genitography image showed the normal urethra and bladder with septum showing a bladder duplication. Distal loopogram was patent

In the evaluation with magnetic resonance imaging (MRI) of the pelvis in Figure 4, it was found that there were multiple fluid lesions in the pelvic cavity about four pockets that were probably interconnected each other. Normal impression of rectum but genitalia were difficult to evaluate.

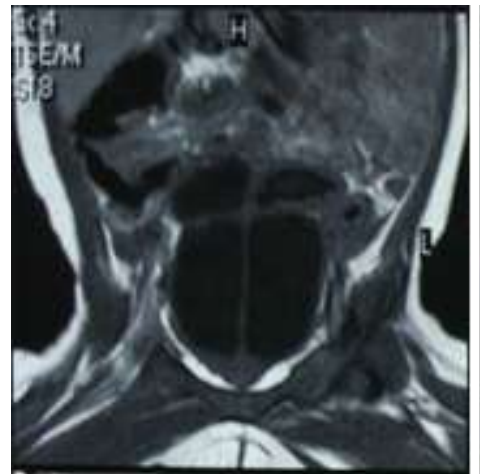

Figure 4. Magnetic resonance imaging (MRI) of the pelvis showed a septated pocket in the pelvic cavity indicating abnormalities in the bladder
In this case, definitive diagnostic was evaluated by performing cystoscopy to directly evaluate the condition inside the bladder. Cystoscopy in Figure 5 showed the urethral was normal, but before entering the bladder, there were septa that extended into the bladder. In the evaluation of the bladder, there were five septa with vertical, horizontal, and oblique positions. The ureteral orificium were difficult to evaluate due to the septa in the bladder. No fistula was found. Then, the cystography was performed during surgery in Figure 6, and obtained multiseptate bladder which divided the right and left bladder. 


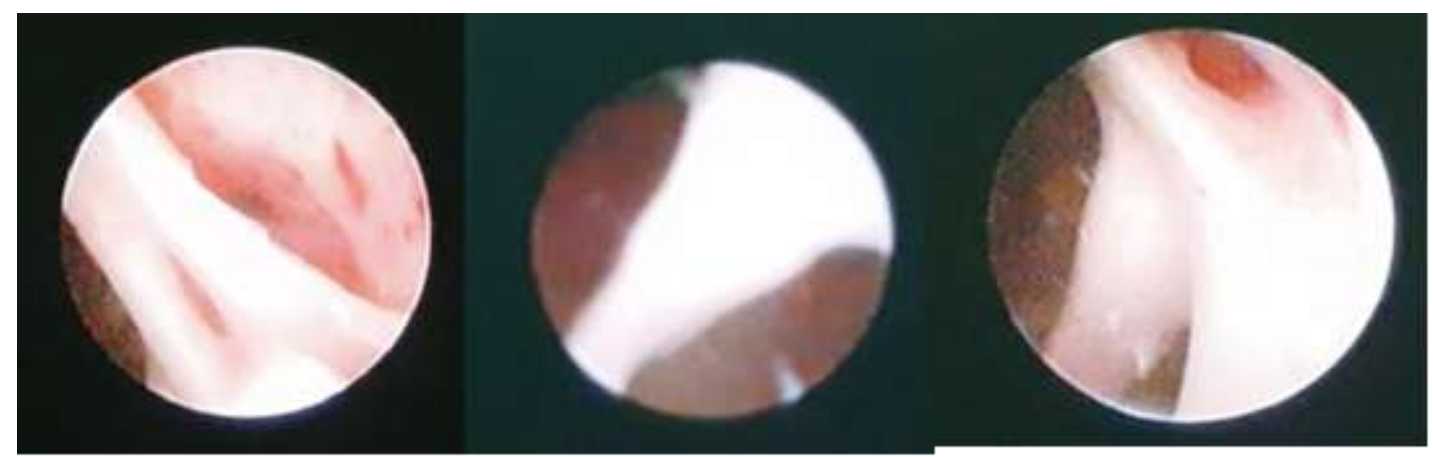

Figure 5. Cystoscopy showed multiseptate in the bladder and the ureteral orificium were difficult to identify
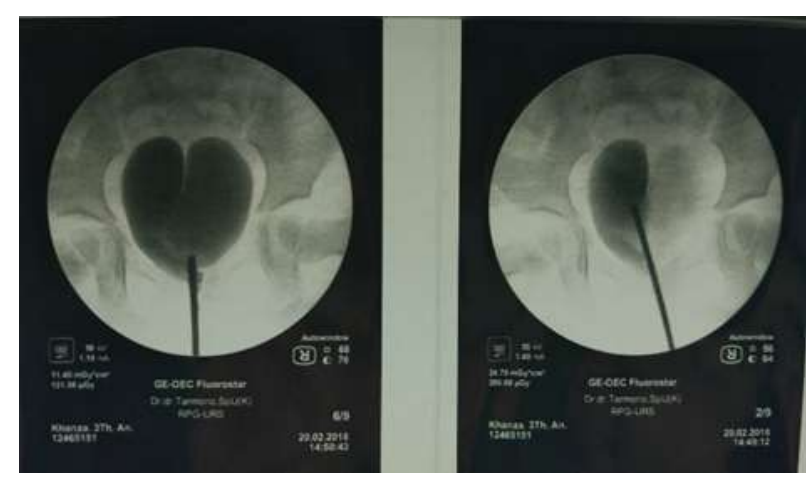

Figure 6. Cystography performed during the operation showed duplication of the right and left bladder

After some diagnostic evaluations with radiological investigations and cystoscopy, there were no conditions that caused obstruction and complications in the upper urinary tract, so that it was decided to be treated conservatively and controlled regularly only if complaints were available.

\section{DISCUSSION}

Congenital anomalies in the bladder have a slight incidence, can vary, and are often accompanied by other congenital anomalies. Bladder anomaly can result urinary tract obstruction (Roy et al 2017, Matsell \& Catapang 2020). Besides, it also results in kidney failure (Frimberger \& Kropp 2016).

Duplication of bladder can arise completely or incompletely (Awashi et al 2015, Tsuji et al 2019, Kuliniec et al 2021). In incomplete duplication, both bladders are interconnected and drained by one urethra, while the complete duplication, the bladder are separated by a wall consisting of mucosa and muscles of varying sizes with two or only one urethra, so that total obstruction can occur on the side that does not have a urethral (Frimberger \& Kropp 2016).
Kohler in Abrahamson (1961) reported a case of multiseptate bladder and other congenital anomalies which was found accidentally at the autopsy of a 10 days aged infant, microscopically found multiple septa formed from fibromuscular layer covered by transitional epithelium which was identical to the histological picture of the bladder wall. Another study also found that multiseptate bladder was also found in 7-year-old girl with 2 years duration of abdominal pain (Bertozzi et al 2019).

In our case, in addition to duplicating bladder patients, genitography, pelvic magnetic resonance imaging (MRI), and cystography were also found to be communicating with one another. Internal evaluation with cystoscopy showed several spaces that communicated each other and separated by numerous septa.

Furthermore, there was no further surgical treatment in the field of Urology, because there were no signs of obstruction in the urinary tract and normal renal function. Oğuzkurt et al (2006) concluded that the goal of therapy in congenital bladder anomaly was to maintain function and drainage of the bladder and minimize the risk of infection. Once no other anomalies are not found, no special action needs to be taken.

\section{CONCLUSION}

The treatment of each bladder anomaly cases were different. The goal of early treatment in every case of bladder anomaly was to avoid obstruction of the genitourinary tract, prevent infection, and maintain the function of both kidneys. In the case of incomplete duplication and multiseptate bladder, it did not cause any symptoms or obstruction in the urinary tract, so that it did not require further surgery in the field of Urology. 


\section{REFERENCES}

Abrahamson J (1961). Double bladder and related anomalies: Clinical and embryological aspects and a case report. British Journal of Urology 33, 195-214.

Bertozzi M, Bizzarri I, Angotti R, et al (2019). Multiseptate gallbladder in a child. Journal of Pediatric Surgery Case Reports 45, 1-4.

Frimberger D, Kropp BP (2016). Bladder anomalies in children. In: Wein AJ (ed). Urology: 11th ed. Elsevier, Philadelphia.

Gajbhiye, Nath S, Ghosh P, et al (2015). Complete duplication of the urinary bladder: An extremely rare congenital anomaly. Urol Ann 7, 91-93.

Jain S, Chen F (2018). Developmental pathology of congenital kidney and urinary tract anomalies. Clinical Kidney Journal 12, 382-399.

Karaca T, Yoldas O, Bilgin BC, et al (2011). Diagnosis and treatment of multiseptate gallbladder with recurrent abdominal pain. Case Reports in Medicine 2011, 1-2.

Matsell DG, Catapang M (2020). Predicting outcomes and improving care in children with congenital kidney anomalies. Pediatric Nephrology 35, 1811-1814.

Oğuzkurt, P, Ozalevli SS, Alkan M, et al (2006). Unusual case of bladder duplication: Complete duplication in coronal plane with single urethra and no associated anomalies. Urology 68, 10-12.
Roy RR, Firozanjum F, Ferdous S (2017). Obstructive uropathy in children - An update. Bangladesh J Child Health 41, 110-116.

Wani IA, Iqbal F, Samoon H, et al (2015). Septum of a bladder. MOJ Clinical \& Medical Case Reports 2, 2-3.

Zhan X, Liu D, Wang G, et al (2021). The innovative use of ureter catheter in the surgery of obstructive uropathy. Computational and Mathematical Methods in Medicine 2021, 1-7.

Patel NR, Joshipura VP, Haribhakti SP, et al (2008). Septate gallbladder in the laparoscopic era. Journal of Minimal Access Surgery 4, 20-22.

Isert S, Müller D, Thumfart J (2020). Factors associated with the development of chronic kidney disease in children with congenital anomalies of the kidney and urinary tract. Front. Pediatr 8, 1-8.

Awasthi NK, Goel H, Mahapatra R, et al (2015). Incomplete bladder duplication with multiple congenital anomalies: A rare presentation. Urol Ann 7, 88-90.

Kuliniec I, Mitura P, Plaza P, et al (2021). Urinary incontinence in adulthood in a course of ectopic ureter - Description of two clinical cases with review of literature. International Journal of Environmental Research and Public Health 18, 1-8.

Tsuji K, Ito A, Kurokawa S, et al (2019). Primary carcinosarcoma of the ureteropelvic junction associated with ureteral duplication. Medicine (Baltimore) 98, 1-8. 